\title{
Woody plant encroachment drives habitat loss for a relict population of a large mammalian herbivore in South America
}

\author{
Erika Cuéllar-Soto ${ }^{*}$, Paul J. Johnson², David W. Macdonald², Glyn A. Barrett ${ }^{3}$, and Jorge Segundo 4 \\ 'Sultan Qaboos University, Department of Biology, Muscat, Oman. Email: e.soto@squ.edu.om, and erika.cuellar71@gmail.com (EC-S). \\ ${ }^{2}$ University of Oxford, Department of Zoology, Wildlife Conservation Research Unit, Recanati Kaplan Centre, Tubney OX13 5QL, \\ Oxon, UK. Email: paul.johnson@zoo.ox.ac.uk (PJ), david.macdonald@zoo.ox.ac.uk (DWM). \\ ${ }^{3}$ School of Biological Sciences, University of Reading, Reading RG6 6UR, UK. Email: glyn.barrett@reading.ac.uk (GB). \\ ${ }^{4}$ Comunidad Rancho Viejo, Isoso, Provincia Cordillera, Santa Cruz Bolivia. (JS). \\ *Corresponding author
}

Woody plant encroachment (WPE) is reshaping the physiognomy of grasslands and savannahs worldwide. At the same time, this habitat conversion is accelerating the loss of associated biodiversity. In general, studies on WPE have focused on abiotic factors, singly or in combination, that trigger this phenomenon. Despite its ecological relevance, very few studies have tackled the effects of WPE-spurred habitat transformation on animal species dependent on relatively open areas such as grasslands and savannas for survival. We studied a relict and almost extinct population of large, herbivorous guanacos (Lama guanicoe) in the Gran Chaco region, Santa Cruz department, Bolivia. We tested whether guanacos were using habitats (at particular and distinct stages of WPE) in relation to their availability. Although this species is considered a generalist herbivore. We tested variation in habitat use focusing on two spatial scales. First, at the landscape level, we performed aerial surveys. Second, at the fine scale, we tracked six groups of guanacos for twenty months and documented the various habitats used within their approximate home ranges. At both scales, we performed a Manly-Chesson's index referring to the standardised proportional use of each habitat divided by the proportional availability of each, with the values for all habitats summing to 1 . An index value $<1$ or $>1$ suggests, respectively, that a habitat is avoided or selected. We found a disproportionate use of open vegetation (scrubland and grassland) by guanacos in relation to habitat availability at both scales. In addition, the current distribution range of the species is restricted to less than $800 \mathrm{~km}^{2}$ of the approximately $3,000 \mathrm{~km}^{2}$ potentially available in 1998 . We confirmed a contraction between 1996 and 2006 in the distribution of the local Chacoan guanaco population from the area where guanacos were first monitored towards the Kaa-lya National Park border. Our results showed that guanacos are restricted to relatively open areas. Furthermore, the observed reduction in the area previously occupied by the species could be the beginning of a distributional shift and potential loss of the guanaco's geographic range due to habitat replacement. The latter was also reflected in a previous dietary study of this population we found that guanacos largely consumed the native grass A. mendocina (Poaceae), which has shrunk in distribution by $90 \%$ in this region over a 40 year period and is gradually being replaced by an invasive forb, Lippia sp. Therefore, if the overall purpose on evaluating habitat use is to understand the basic requirements to sustain this population of guanacos, we need to highlight the poor quality and acute regression of the current preferred habitat. In this case, habitat structure can have a profound effect on the success of the guanaco population recovery and its long-term establishment. Therefore, we urge researchers and decision makers to look beyond the more direct human-induced pressures on the species, such as hunting, competition with domestic livestock and agricultural development and consider the importance of WPE as a direct driver for habitat loss.

El incremento de la vegetación arbustiva está reformando la fisonomía de los pastizales y sabanas a lo largo del mundo y acelerando la pérdida de la biodiversidad. En general, los estudios sobre arbustización se han focalizado en factores abióticos, actuando tanto en forma individual como combinados, que han disparado el fenómeno. A pesar de su relevancia ecológica, muy pocos estudios han enfrentado los efectos derivados de la transformación del hábitat vía arbustización, sobre especies dependientes, para su supervivencia, de áreas relativamente abiertas, tales como pastizales o sabanas. Nosotros estudiamos una población relictual y casi extinta de un gran herbívoro, el guanaco Lama guanicoe en la región del Gran Chaco en Bolivia. Allí pusimos a prueba la hipótesis de que los guanacos están usando hábitats (en diferentes estados de arbustización) con relación a su disponibilidad. Además evaluamos la prueba la variación en el uso del hábitat enfocado a dos escalas espaciales. Primero, a nivel de paisaje, a partir de reconocimientos aéreos. Segundo, a una escala fina, seguimos en el campo 6 grupos de guanacos durante 20 meses y registramos su uso de hábitat dentro de sus ámbitos de hogar aproximados. Para ambas escalas, aplicamos el índice de Manly-Chesson. Un valor del índice $<1$ o $>1$ sugiere que el hábitat es evitado o seleccionado, respectivamente. Encontramos que los guanacos usan la vegetación abierta (matorral y pastizal) en forma desproporcionada en relación con la disponibilidad de los hábitats para ambas escalas de abordaje. Además, que la actual distribución geográfica de la especie está restringida a menos de $800 \mathrm{~km}^{2}$ de los ca. 3,000 km² potencialmente disponibles en 1998. Confirmamos una retracción, entre 1996 y 2006 en la distribución del guanaco chaqueño a partir del área donde fue monitoreado por primera vez hacia el límite del Parque Nacional Kaa-lya. Nuestros resultados mostraron que los guanacos están restringidos a las áreas relativamente más abiertas. Además, que la reducción observada en el área previamente ocupada por la especie podría constituir el comienzo de un cambio distribucional y una potencial pérdida de rango geográfico para el guanaco, debido al reemplazo de hábitat. Esto último sumado a que la gramínea nativa Aristida mendocina (Poaceae), especie preferida en la dieta del guanaco chaqueño, está siendo gradualmente reemplazada por una leñosa invasora, Lippia sp. Por lo tanto, si el propósito global de la evaluación del uso de hábitat es comprender los requerimientos básicos para sostener esta población de guanacos, necesitamos destacar la pobre calidad y aguda regresión de su hábitat preferido contemporáneo. En este caso, la estructura del hábitat puede tener un profundo efecto sobre el éxito de la recuperación de la población de guanaco y su sostenibilidad a largo plazo. Por lo tanto, urgimos a los investigadores y gestores a considerar la importancia de la arbustización como un factor directo conducente a la pérdida de hábitat y una amenaza inminente a la biodiversidad regional.

Keywords: Bolivia; Gran Chaco; Lama guanicoe; Pampas; tropical dry forest; "thicketisation" of savannahs. 


\section{Introduction}

Habitat loss is most often perceived to be caused by discernibly drastic factors such as clear-cutting of forest for the expansion of agriculture (Andren 1997). In contrast, a more subtle, transformative pressure on vegetation communities is "woody plant encroachment" (WPE; Archer et al. 2017), also known as the "thicketisation" of grasslands (Archer et al. 1995). This phenomenon of WPE has increased worldwide over the past century, albeit at different rates in different continents (Sankaran et al. 2005; Sala and Maestre 2014; Archer et al. 2017; Stevens et al. 2017; Garcia-Criado et al. 2019). Despite its ecological relevance, there is a general recognition of the complexity in identifying the main causative drivers for this phenomenon; especially since variations in time, land-use history and bioclimatic zones need to be taking into account (Van Langevelde et al. 2003; Sankaran et al. 2005; Kulmatiski and Beard 2013; Archer et al. 2017). Furthermore, WPE-driven reshaping of the physiognomy of grasslands and savannas (Kenoyer 1929; Van Auken 2000; Scheffer et al. 2001; Graz 2008) has effectively resulted in their overall depletion of these habitats with associated declines in plant species richness (Ratajczak et al. 2012), or their degradation (Baez and Collins 2008). In addition, the specific consequences for ecosystem function and biodiversity are variable (Barger et al. 2011; Eldridge et al. 2011) from overall declines across trophic levels to expansion or reduction of specialist species ranges, among many other changes reviewed by Garcia-Criado et al. (2019). Furthermore, WPE could be a significant pressure on both grazing and browsing herbivores, causing perhaps reductions in forage value (Eldridge et al. 2011), and therefore transforming the structure of the vegetation communities that make up their habitats.

As stated by Archer et al. (2017) very little is known regarding specific responses of animals to WPE-driven habitat transformation. There are a few studies relating habitat transformation to different components of biodiversity such as birds (Knopf 1994; Coppedge et al. 2001; Skowno and Bond 2003; Coppedge 2004; Cunningham and Johnson 2006; Sirami et al. 2009; Block and Morrison 2010; Sirami and Monadjem 2012), arthropods (Steenkamp and Chown 1996; Blaum et al. 2009), and reptiles (Mendelson and Jennings 1992; Meik et al. 2002; Pike et al. 2011). However, to the best of our knowledge, there are only around a dozen specific studies on the consequences of shrub encroachment on mammals in general (Kavwelle et al. 2017). Examples of the latter are, specifically rodents (Blaum et al. 2007a; Emmons 2009; Bilney et al. 2010; Pardiñas et al. 2012; Pardiñas and Teta 2013), carnivores (Blaum et al. 2007b), and ungulates (Okello 2007; Kimaro et al. 2019). Among the latter, only a few have explored the disruption caused by WPE on mammalian species dependent on relatively open areas such as grasslands and savannas (Krogh et al. 2002; Blaum et al. 2007a).
In South America, one of the largest native mammalian herbivores, strongly associated with grasslands, with the exception of the cold forests in Tierra del Fuego (Muñoz and Simonetti 2013), is the guanaco Lama guanicoe (Miller et al. 1973; Franklin 1982, 1983; Travaini et al. 2007). Despite guanaco presence in four of the ten major ecoregions described in South America, the distribution range of this species has contracted by $60 \%$ during the last century (Gonzalez et al. 2006). The situation is further exacerbated with local extinctions and isolation of guanaco populations within its current distribution range (Miller et al. 1973; Sosa and Sarasola 2005; Gonzalez et al. 2006; Cuellar-Soto et al. 2017a; CookMena et al. 2019). Strikingly, despite the latter, the guanaco continues to be categorized as of least concern (LC) by the IUCN (Baldi et al. 2016). However, three (Perú, Bolivia and Paraguay) of the five countries that acknowledge this incongruity have changed the guanaco's conservation status to Endangered (EN) and Critically Endangered (CR; Cuéllar and Núñez 2009; Cartes et al. 2017; SERFOR 2018).

In Bolivia, we studied the relict and isolated population of around 200 Chacoan guanacos, which constitutes the north-eastern fringe of the species range (Cuéllar and Núñez 2009). At the same time, this population is restricted to an area characterized by a mosaic of vegetation in different stages of the WPE process, with variations in height (0.4 to 4 metres) and thickness (Navarro and Fuentes 1999; Pinto and Cuéllar-Soto 2017).

We tested differential use of habitats at different stages of WPE by guanacos in relation to their availability, both at a landscape and home range scale. Although guanacos are considered as generalist herbivores (Raedeke and Simonetti 1988; Puig et al. 2001; Puig et al. 2011), we hypothesized that guanacos prefer native grasslands and the early stages of encroachment together with the remaining of native grasslands over other available habitats. Finally, we hypothesised that WPE is causing contraction of potential suitable habitat for the Chacoan guanacos.

\section{Materials and Methods}

The study area extends from $-19^{\circ} 45^{\prime}$ to $20^{\circ} 30^{\prime} \mathrm{S}$ and from $-62^{\circ} 00^{\prime}$ to $63^{\circ} 00^{\prime} \mathrm{W}$, on the fluvial megafans of the Río Grande and the Río Parapetí in the Bolivian Gran Chaco (May et al. 2008), in the extreme south of Santa Cruz department, Bolivia. The study area includes the southwest corner of the Kaa-lya National Park and part of the Indigenous Isoseño Communal Land (Figure 1). The climate is predominantly semi-arid (Peel et al. 2007), with annual rainfall ranging from 200 to $350 \mathrm{~mm}$ (Taber et al. 1997).

We used the information on the expansion of each vegetation community from the vegetation maps produced by Pinto and Cuéllar-Soto (2017b). The latter is based on Navarro's classification of stages of WPE in the study area (open forest, thick woodland, shrubland, scrubland, grassland) according to their structure ( 0.40 to 4 metres), species composition and cover (Navarro and Fuentes 1999). 
The total area covered by our aerial surveys (Figure 2) was the potential guanaco range. We defined the latter by taking into account: 1) earlier guanaco observations and interviews with local people (Villalba 1992; Emmons 1993; Anderson 1997; Cuéllar and Fuentes 2000), and 2) the potentially suitable habitats, including all main expansions of savannahs and relatively open vegetation on sandy soil covering around $3,000 \mathrm{~km}^{2}$ (Cuéllar and Fuentes 2000). In addition, we compared the observations gathered in a specific area, between 1996 and 1998 (Miserendino et al. 1998; Weber 2000), to those collected between 2005 and 2006 to confirm retraction in part of the guanacos' local distribution range.

At the landscape level, we determined the distribution of guanacos from aerial surveys in April 1998, December 2001 and December 2004, and confirmed in subsequent aerial surveys (2008 and 2011). We used a single-engine light aircraft (Maule ML5) during peak periods of guanaco foraging activity (early morning from 6 to 8 AM) when guanacos were most likely to be visible and hence detected. We maintained a constant height of approximately 100 $\mathrm{m}$ above ground level at an average speed of $180 \mathrm{~km} / \mathrm{hr}$ along fixed-width strip transects ( $450 \mathrm{~m}$ to each side of the aircraft), oriented north-south. We defined the "usage" of habitat as a given area at a radius of $450 \mathrm{~m}$ around each guanaco observation point from the plane. Determination

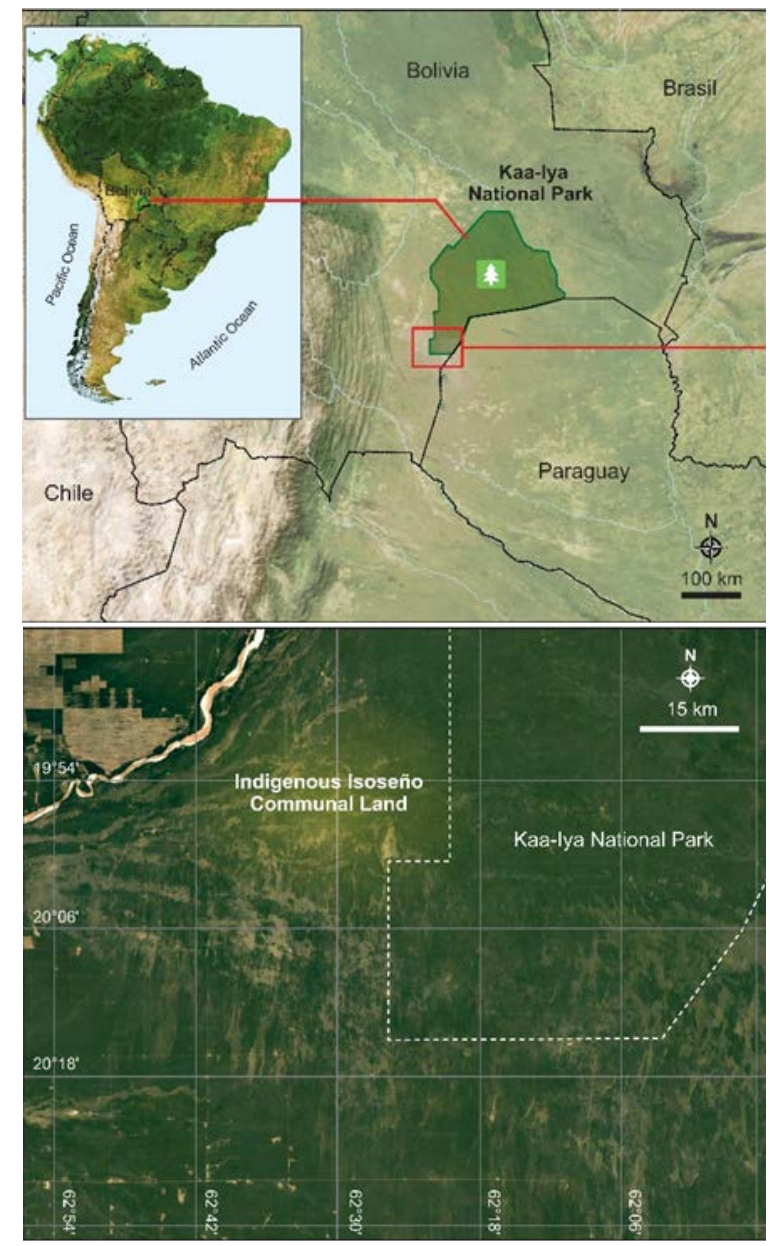

Figure 1. The study area is in the extreme south of the Santa Cruz department of Bolivia and less than $100 \mathrm{~km}$ from the Paraguayan border. It is part of the Indigenous Isoseño Communal Land and includes the southwest corner of the Kaa-lya National Park. of this area was resolved using either side of the aerial transect as a measure, together with the visibility we had from the plane. In addition, we defined as habitat availability the total area during the first aerial survey.

On a fine scale, for the purposes of analysis, we selected the information gathered for only six distinct guanaco groups tracked for twenty months (between 2007 and 2009) and recorded the habitat used within their approximate home ranges. These small groups of between two to four adults with one or two newborns or sub-adults (Table 1 ), remained in the same general area throughout the year. Group composition did not vary during the monitoring period. We identified groups from variations in phenotypical traits and morphological characteristics such as scars, fur colour variations in males, and group composition (Cuéllar and Noss 2014) - an approach similar to that used to identify other species with subtle differences in skin patterns, such as puma Puma concolor (Kelly et al. 2008). We used roads and trails as fixed transects crossing different habitats within the vegetation mosaic. Mean transect length, travelled on foot or on horseback, was $10.5 \mathrm{~km}$ (range: 7 to14 km). Locations of identified guanacos were recorded and mapped using ArcView (Environmental Systems Research Institute, Redlands, USA). Minimum home ranges (utilized habitats) were estimated using Minimum Convex Polygons (sensu Mohr 1947) and Animal Movement Analysis Extension (Hooge and Eichenlaub 1997). Using Ranges7 software (South et al. 2005), we determined the core area (Kernel $99 \%$ ) of the guanaco population from cumulative observations and determined it as available habitats.

At both scales [1) the landscape level, habitat within the $450 \mathrm{~m}$ radius buffer around each observation location versus total area surveyed with the aircraft. And 2) the fine scale, home ranges versus core area of the study population] we performed a Manly-Chesson's index referring to the standardised proportional use of each habitat divided by its proportional availability, so the values for all habitats sum to 1 (Manly et al. 1972; Chesson 1978). An index value $<1$ or $>1$ suggesting, respectively, that the habitat is avoided or selected.

Finally, we plotted the observations recorded in two periods, the first between 1996 and 1998 and the second between 2005 and 2006. Data was gathered using the

Table 1. Composition of the six groups identified and monitored, identification number, sex, newborns and sub-adults.

\begin{tabular}{lccccc}
\hline Group ID & Number & Male & Female & Newborn & Sub-adult \\
\hline G1 & 5 & 1 & 3 & 1 & 0 \\
G2 & 5 & 1 & 2 & 2 & 0 \\
G3 & 7 & 1 & 4 & 2 & 0 \\
G4 & 6 & 1 & 4 & 0 & 1 \\
G5 & 1 & 1 & 0 & 0 & 0 \\
G6 & 3 & 1 & 2 & 0 & 0 \\
\hline
\end{tabular}




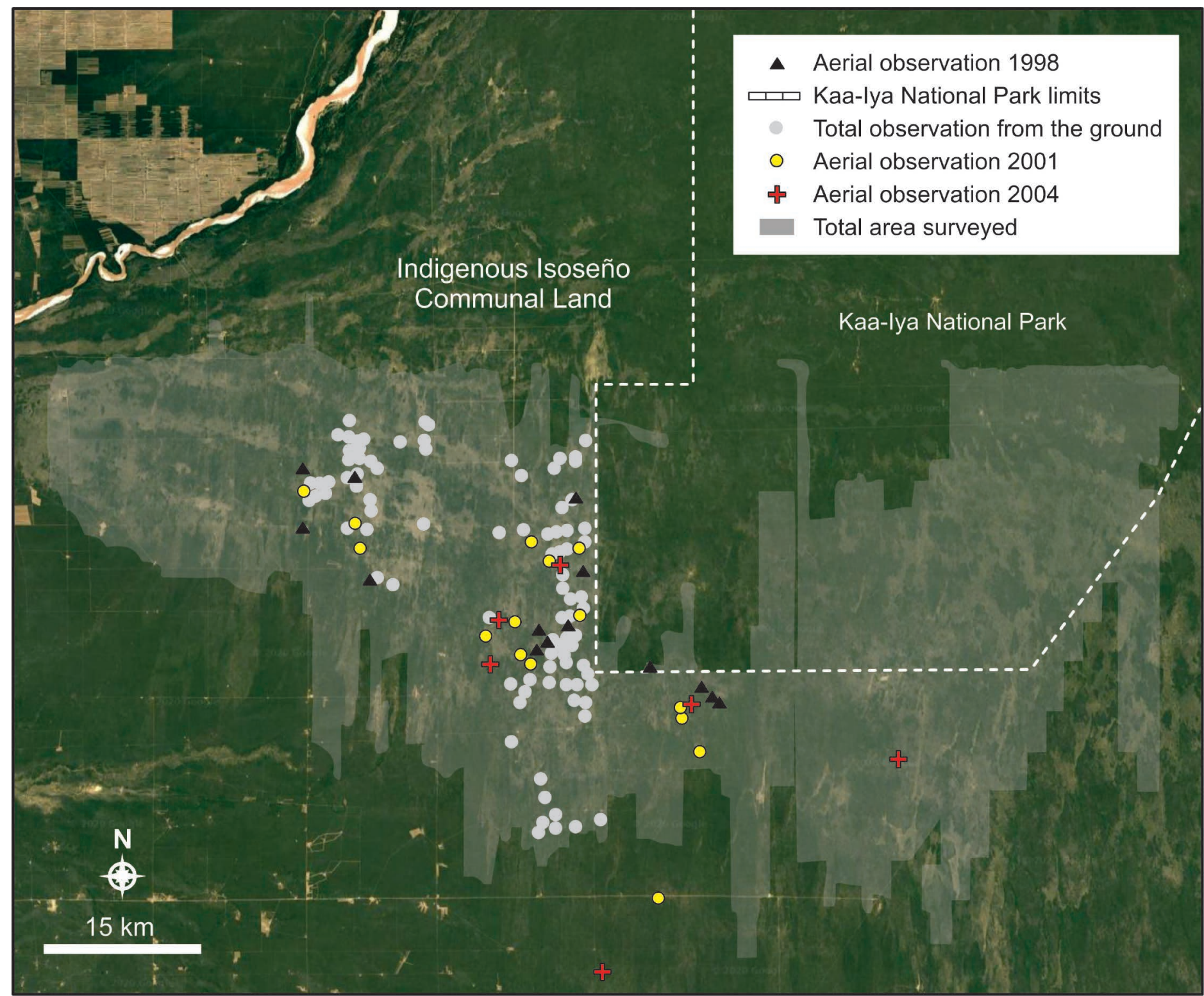

Figure 2. The total area covered by the aerial surveys. The total area covered by our aerial surveys (in grey). This area surveyed represents the potentially suitable habitats on sandy soil covering around $3,000 \mathrm{~km}^{2}$.

same methodology (by foot or on horseback) and by the same core of observers on a map including the borders of the newly created Kaa-lya del Gran Chaco National Park.

\section{Results}

We estimated the Chacoan guanaco range to be less than $800 \mathrm{~km}^{2}$ from the approximately $3000 \mathrm{~km}^{2}$ potentially available in 1998. The same broad distribution was confirmed 13 years later by subsequent aerial surveys (2001, 2004, 2008,2011 ) and in 2020 by monthly reports of the Kaa-lya National Park para-biologists and park rangers.

At a landscape level, the proportions of habitat categories available in the landscape versus proportions utilised (within a $450 \mathrm{~m}$ radius of observations during aerial surveys) are presented in Table 2 . In addition, Manly-Chesson index values suggested consistent patterns in use of the study area by guanacos (Figure 3). Index values calculated for the three aerial surveys (1998, 2001, and 2004) were each $>1$ indicating that the combination of scrubland and grassland was the favoured habitat type over shrubland, thick woodland and open forest.

At a fine scale, the mean home range of these guanaco groups, which maintained constant familial compositions throughout the study period, was $24 \mathrm{~km} 2$ ( \pm 14 SD; $N=6$, range: 13 to $51 \mathrm{~km}^{2}$; Cuéllar and Noss 2014). The proportions of habitat categories available within the guanaco population core area versus proportions within minimum convex polygon (MCP) - approximate home ranges- of six guanaco groups are presented in Table 3. Manly-Chesson index values were not consistent between groups and are presented in Figure 4. In fact, the index value was $>1$ for only two (G1 and G4) of the six groups, with a scrubland/ grassland type habitat combination clearly favoured by these two groups over other available habitat types (shrubland, thick woodland and open forest). In contrast, the index value for group five (G5) suggested preference for shrubland and thick woodland. Two groups (G2 and G3) showed preference for the combination of scrubland and 
Table 2. Landscape level analysis: Proportions of habitat categories available in the landscape versus proportions utilized (within a 450m radius of observations during aerial surveys). Habitat type Available \% (1998) Mean \% habitat use Available \% (2001) Mean \% habitat use Available \% (2004) Mean \% habitat use

\begin{tabular}{lrrrrrr}
\hline Open Forest & 30.8 & 2.5 & 19.0 & 13.0 & 41.2 & 7.6 \\
Thick woodland & 10.9 & 2.3 & 15.9 & 3.2 \\
Shrubland & 23.0 & 20.8 & 34.1 & 21.9 & 21.9 \\
Scrubland+Grassland & 35.3 & 74.26 & 35.4 & 57.5 & 25.9 \\
\hline
\end{tabular}

grasslands plus shrubland with the remaining group (G6) only showing avoidance for open forest.

When records from two periods were plotted, we observed a contraction in part of the local distribution towards the Kaa-lya National park border, between 19961997 and 2005-2006 (Figure 5), the latter confirming the comments from local ranchers.

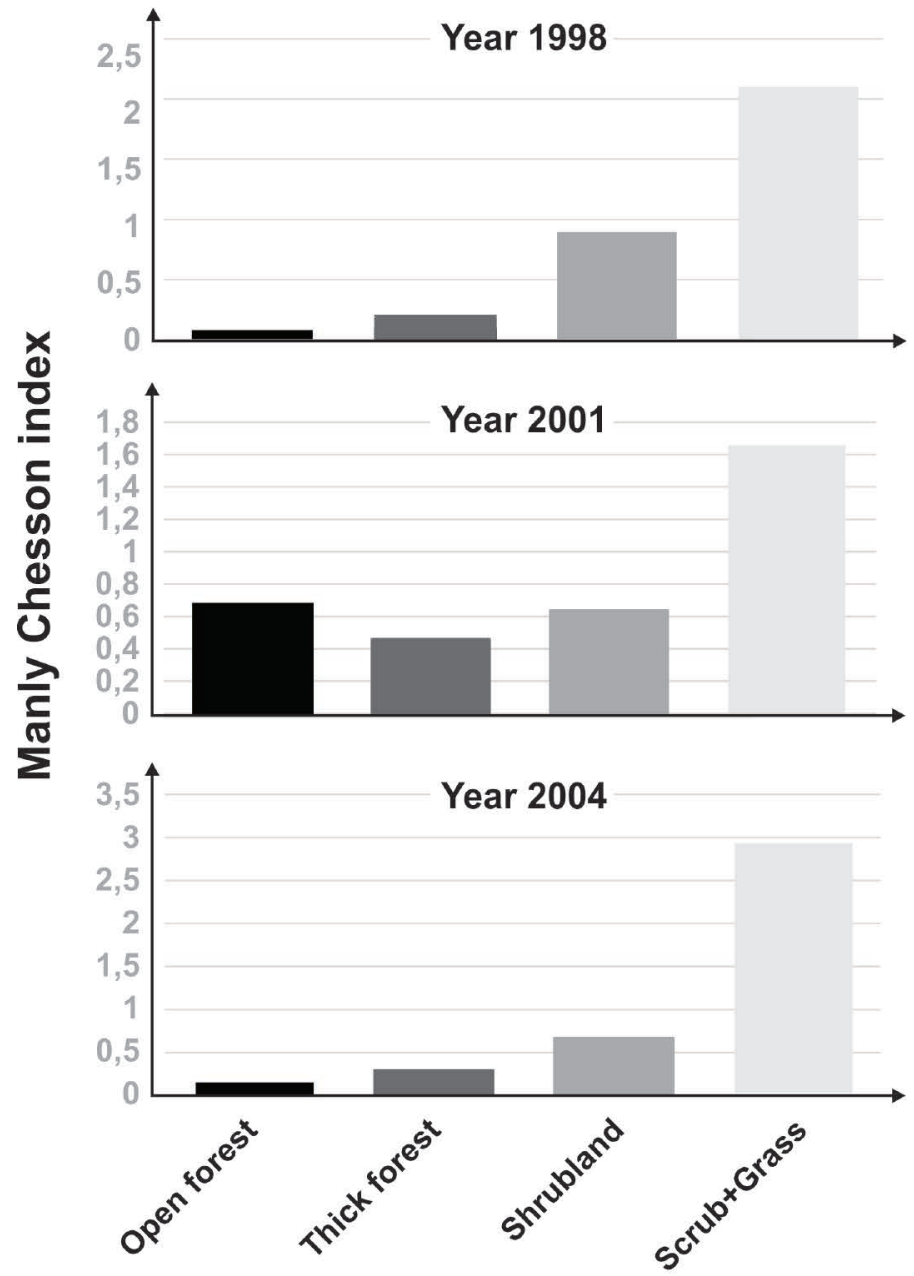

Type of vegetation

Figure 3. Manly-Chesson index values for the three aerial surveys $(1998,2001$ and 2004) suggested consistent patterns in use of the study area by guanacos. Index values $>1$ indicates that the combination of scrubland and grassland was the favoured habitat type over shrubland, thick woodland and open forest.

\section{Discussion}

This study is the first investigation on use of habitat by a relict population of guanacos in the Bolivian Gran Chaco. First, our results supported the prediction that, at a landscape scale, guanaco showed preference to areas where the early stages of woody plant encroachment were relatively low. The latter is not surprising since a previous study showed that Chacoan guanacos are largely pastoral (Cuéllar-Soto et al. 2017b). However, these grassy areas, consisting mainly of communities of the native grass Aristida mendocina (Poaceae), are themselves disappearing due to different stages of WPE (Pinto and Cuéllar-Soto 2017), starting with the gradual replacement of $A$. mendocina by an invasive forb Lippia sp. (Navarro 2002). Therefore, if the overall purpose on evaluating habitat use is to understand the basic requirements to sustain this population of guanacos, we need to highlight the poor quality and acute regression of the current preferred habitat. In this case, habitat structure can have a profound effect on recovery success of the guanaco population and its long-term establishment. On one hand, the loss of suitable habitat could affect food availability for guanacos, owing to the replacement of palatable plants by unpalatable woody species and annuals as previously reported from studies in South Africa (Chambers et al. 1999), Australia and the United States of America (Janssen et al. 2004). On the other hand, effective detection of predators can be impeded by WPE through deteriorations in guanaco visibility (e. g. Riginos and Grace 2008; Underwood 1982). Therefore, WPE is likely to have a negative effect on the ability of guanacos and other species living in open environments, reliant on sight, to detect predators (Kunkel and Pletscher 2000; Barri and Fernández 2011; Flores et al. 2012). In addition, Bank et al. (2002) reported that puma kills on guanacos were significantly more frequent in habitat with dense cover (mainly shrubland) and suggested that guanacos' selection for open and flat terrain is a critical component of their predator avoidance strategy and long-term survival. Similarly, Owen-Smith (2008) argued that shorter grass height can reduce the predation vulnerability of wildebeest Connochaetes taurinus and zebra Equus burchelli in Africa.

Furthermore, we observed some differences at a home range scale in the use of habitat among the groups. The index values for G1, G2, G3 and G4, suggested that the combination of scrubland and grassland habitat type was favored over shrubland, thick woodland and open forest. Interestingly, those groups had the highest numbers with either a newborn or subadult as part of the family group. In contrast, G5 and G6 were groups of two couples without offspring. This latter point could raise the question as to whether habitat preference is more notably linked to reproduction and survival (Garshelis 2000), so, in effect, does our observed pattern suggest a limitation of the 

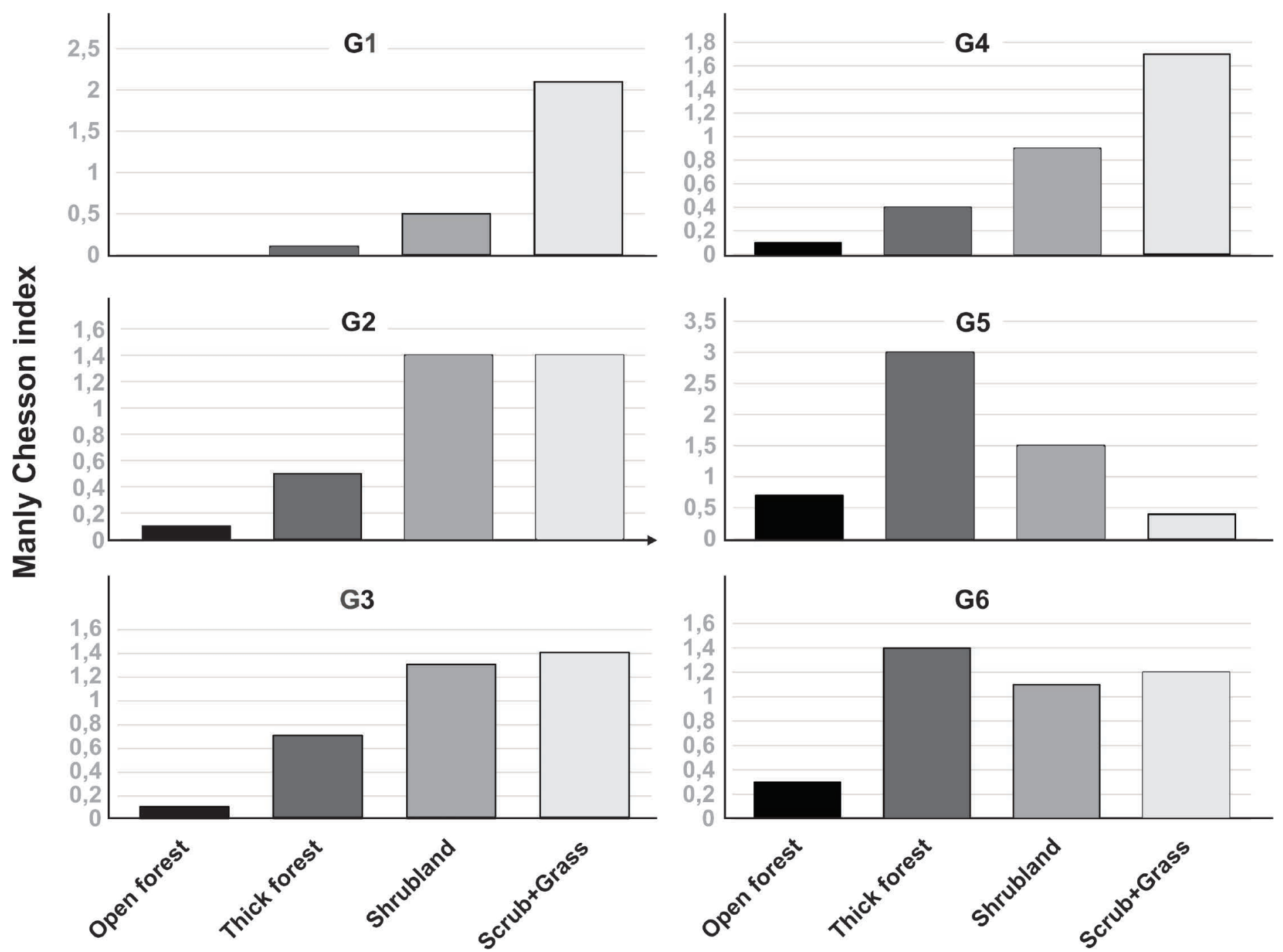

\section{Type of vegetation}

Figure 4. Manly-Chesson index values for the six groups (G1, G2, G3, G4, G5, and G6). The index value $>1$ for scrubland/grassland type habitat combination clearly showed that G1 and

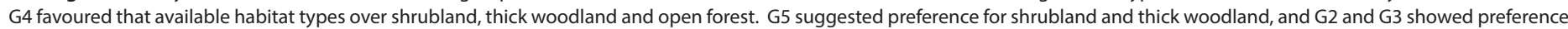
for the combination of scrubland and grasslands plus shrubland. G6 only showed avoidance for open forest.

current mosaic for supporting population growth? If true, can we assume that the guanaco population in question is under risk of early extinction? To help answer this question additional information and monitoring data acquired from recent technological advances and field equipment is required. This may involve the use of expandable GPS collars for subadults to assess individual patterns of dispersion following expulsion from the family group. However, any attempt to capture and tag Chacoan guanacos should consider the current situation of such a small and fragile population and the risk of having animals escaping into dense vegetation and or barb-wired borders of private ranches, at a risk to themselves. Given the low visibility and the small chances to encounter the guanacos, which is extremely contrasting to any other population studied on the continent (Cunazza et al. 1995; Baldi et al. 2009; Sosa and Sarasola 2005; Arzamendia et al. 2006; Puig et al. 2008; Cassini et al. 2009; Acebes et al. 2010; Burgi et al. 2011; Parreño et al. 2001; Flores et al. 2012; Cook-Mena et al. 2019; Puig et al. 2019), the use of horses is recommended. Furthermore, researchers should expect to invest a lot of physical effort and time, including travelling long distances

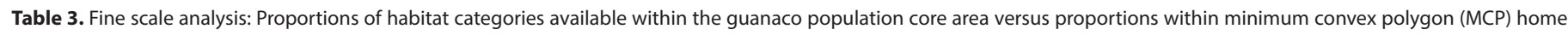
ranges of six guanaco groups.

\begin{tabular}{lrrrrrrr}
\hline \multicolumn{1}{c}{ Habitat type } & \% habitat available & MCP 1 & MCP 2 & MCP 3 & MCP 4 & MCP 5 & MCP 6 \\
\hline Open Forest & 25.0 & 0.0 & 3.0 & 3.7 & 2.3 & 18.9 & 7.9 \\
Thick woodland & 9.5 & 1.0 & 4.7 & 6.9 & 3.7 & 29.4 \\
Shrubland & 24.6 & 12.3 & 34.9 & 32.8 & 23.3 & 36.9 & 28.8 \\
Scrubland+Grassland & 40.7 & 86.5 & 57.3 & 56.3 & 70.5 & 14.6 \\
\hline
\end{tabular}




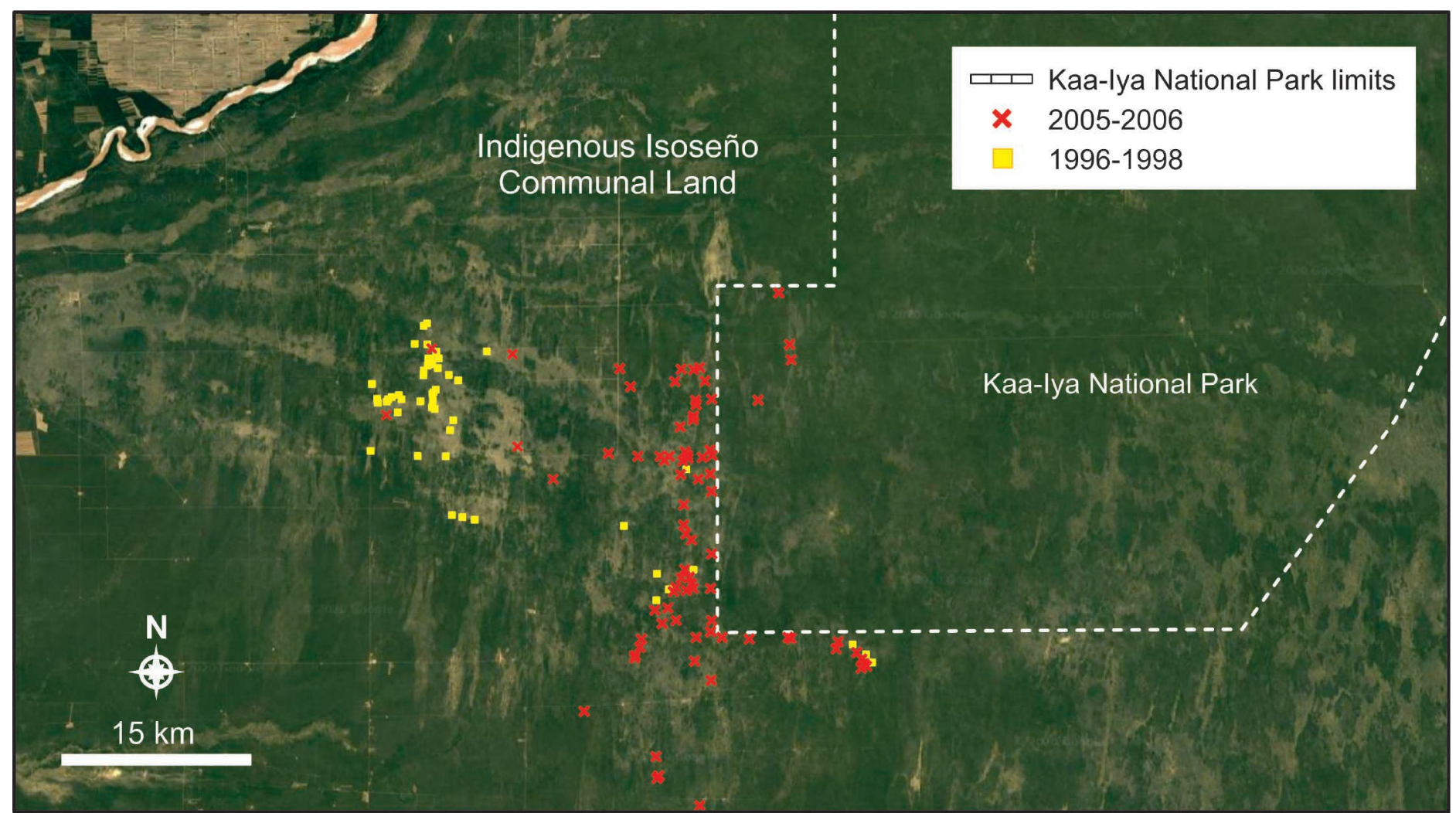

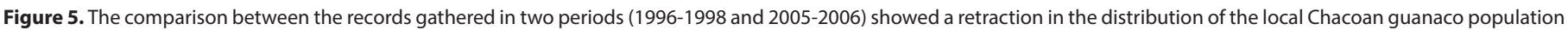
towards the Kaa-lya National Park border.

over several days and rough terrain without observing any guanacos.

In addition, on both scales, our results showed that guanacos were concentrated within the same broad range and within the most open areas, suggesting that this guanaco population is sedentary. According to Franklin and Fritz (1991) guanacos can be sedentary or migratory in response to food availability. However, there is no suitable habitat into which guanacos can expand their range unless effective management interventions are implemented on the respective ranch properties, indigenous communal lands, and a portion of the Kaa-lya National Park currently occupied by the guanacos. At present, almost the entire guanaco population is restricted to private lands and indigenous communal land. On one hand, the private lands are mainly cattle ranches with evident degradation of pasture and invasion by woody plants (Angulo and Rumiz 2009). On the other hand, and with a more promising prospect, there has been a recently approved municipal law ("Ley autonómica No 034/2019 ley de creación, conservación del Área de Vida del Guajukaka (guanaco) en la Zona Alto Isoso (AVIGUZI ) y Protección del Guajukaka (guanaco) en Charagua lyambae") declaring an area of $2,500 \mathrm{Km}^{2}$ as a municipal reserve for guanacos. The latter will encourage further efforts for the protection of the species.

Second, our results also supported the prediction that WPE is causing a contraction of potential suitable habitat for the Chacoan guanacos. We observed a contraction in the area previously occupied by the species (Miserendino et al. 1998; Weber 2000) which could be the beginning of a distributional shift and potential loss of the guanaco's geographic range due to habitat replacement, as has been suggested for past geographic distributions of the species in Argentina (Tonni and Politis 1980; Barberena et al. 2009). The most obvious explanation for this contraction is the intensive development of a cattle ranch in the area (Angulo and Rumiz 2009). In addition, given the general strong association between guanacos and their preferred open habitats (Travaini et al.2007), together with the reduction by $90 \%$ of grasslands due to WPE (Pinto and Cuéllar-Soto 2017), could be engendering a setback for the long-term survival of the guanaco population under study. There are cases where long-term changes in the structure and composition of grasslands have bolstered declines of small mammal communities (Emmons 2009; Bilney et al. 2010; Pardiñas et al. 2012; Pardiñas and Teta 2013).

Even though we are concerned by the multiple factors, such as cattle ranching, change in fire regime (severity and frequency), and soil erosion, driving woody plant encroachment (Morello and Adamoli 1974; Devine etal.2017), we urge for a particular focus on conservation efforts in countering consequences of WPE (Midgley and Bond 2001; Moncrieff et al. 2009; Kgope et al. 2010; Cipriotti and Aguiar 2012). Therefore, we appeal to researchers and decision makers to look beyond the more obvious human-induced pressures on the species (including hunting, competition with domestic livestock and habitat loss or fragmentation resulting from agricultural development; Cunazza et al. 1995) and consider the importance of WPE as a direct driver for habitat loss (Wigley et al. 2010). 
Furthermore, we encourage managers of the $2,500 \mathrm{~km}^{2}$ reserve, recently created by the Indigenous Autonomous Government of the Bolivian district of Charagua, to adapt their management interventions and conservation strategies, and take into consideration this silent but pernicious process of "thicketisation" of savannahs and grasslands. Finally, we encourage and promote the development of additional studies on this phenomenon given that it could constitute an imminent threat to the region's biodiversity (Archer et al. 2017).

\section{Acknowledgments}

We are grateful to several institutions for providing funds, The Wildlife Conservation Society, The Gordon and Betty Moore Foundation within the Amazon-Andes Conservation Program (AACP), The Shared Earth Foundation, Whitley Fund for Nature, and Kaa-lya Foundation. We also thank the great job of para-biologists and park rangers from the Kaa-lya National park. U. F. J. Pardiñas kindly reviewed the Spanish abstract and D. Voglino helped with the edition of the figures, and A. J Noss, R.L. Cuellar and L. James for their involvement in the project.

\section{Literature Cited}

Acebes P., J. Traba, J. E. malo, R. Ovejero, and C. E. Borghi. 2010. Density and habitat use at different spatial scales of a guanaco population (Lama guanicoe) in the Monte desert of Argentina. Mammalia 74:57-62.

Anderson, S. 1997. Mammals of Bolivia: taxonomy and distribution. Bulletin of the American Museum of Natural History 231:1-652.

ANDREN, H. 1997. Habitat fragmentation and changes in biodiversity. Pp. 171-181 in Boreal ecosystems and landscapes: Structures, processes and conservation of biodiversity (Hansson, L. ed.). Ecological Bulletins, Oikos Editorial Office. Copenhagen, Denmark.

Angulo S., And S. Rumiz. 2009. Perceptions about cattle management and its interaction with wildlife in the southwest of Kaa-lya Park (Charagua Municipality). Revista Boliviana de Ecología y Conservación Ambiental 25:69-77.

Archer, S., D. S. Schimel, ANd E. A. Holland. 1995. Mechanisms of shrubland expansion - land use, climate or $\mathrm{CO}_{2}$. Climatic Change 29:91-99.

Archer S. R., E. M. Andersen, K. I. Predick, S. Schwinning, R. J. SteIDL, AND S. R. Woods. 2017. Woody Plant Encroachment: Causes and Consequences. Pp 25-83 in Rangeland Systems (Briske, D. ed.). Springer Series on Environmental Management. Springer. Cham, Switzerland.

Arzamendia, Y., M. H. Cassini, And B. L. Vila. 2006. Habitat use by vicuna Vicugna vicugna in Laguna Pozuelos Reserve, Jujuy, Argentina. Oryx 40:198-203.

Baez, S., and S. Collins. 2008. Shrub invasion decreases diversity and alters community stability in northern Chihuahuan desert plant communities 3:e2332.

Baldi, R. B., P. Acebes, E. Cuéllar, M. Funes, D. Hoces, S. Puig, and W. L. FrankLin. 2016. Lama guanicoe. In: The IUCN Red List of Threatened Species. DOI: 10.2305/IUCN.UK.2016- 1.RLTS. T11186A18540211.en.
Baldi, R., A. Pelliza-Sbriller, D. Elston, and S. Albon. 2009. High potential for competition between guanacos and sheep in Patagonia. Journal of Wildlife Management. 68:924-938.

Bank, M. S., R. J. Sarno, N. K. Campbell, and W. L. Franklin. 2002. Predation of guanacos (Lama guanicoe) by southernmost mountain lions (Puma concolor) during a historically severe winter in Torres del Paine National Park, Chile. Journal of Zoology 258:215-222.

Barberena R, A. F., Zangrando, A. F. Gil, G. A. Martinez, G. G. Politis, L. A. Borrero, and G. A. Neme. 2009. Guanaco (Lama guanicoe) isotopic ecology in southern South America: spatial and temporal tendencies, and archaeological implications. Journal of Archaeological Science 36:2666-2675.

Barger, N. N, S. Archer, J. Campbell, C. Huang, J. Morton, and A. K. KNAPP. 2011. Woody plant proliferation in North American drylands: A synthesis of impacts on ecosystem carbon balance. Journal of Geophysical Research: Biogeosciences 116:G00K07. BarRI, F. R., AND M. Fernández. 2011. Foraging and vigilance time allocation in a guanaco (Lama guanicoe) population reintroduced in Quebrada del Condorito National Park (Córdoba, Argentina). Acta Ethologica 14:103-107.

Bilney, R. J., R. Cooke, ANd J. G. White. 2010. Underestimated and severe: Small mammal decline from the forests of southeastern Australia since European settlement, as revealed by a top-order predator. Biological Conservation 143:52-59.

Blaum, N., C. Seymour, E. Rossmanith, M. Schwager, and F. Jeltsch. 2009. Changes in arthropod diversity along a land use driven gradient of shrub cover in savanna rangelands: Identification of suitable indicators. Biodiversity and Conservation 18:1187-1199.

Blaum, N., E. Rossmanith, A. Popp, and F. Jeltsch. 2007a. Shrub encroachment affects mammalian carnivore abundance and species richness in semiarid rangelands. Acta Oecologica31:86-92.

Blaum, N., E. Rossmanith, and F. Jeltsch. 2007b. Land use affects rodent communities in Kalahari savannah rangelands. African Journal of Ecology 45:189-195.

BLock, G., AND M. L. MorRIson. 2010. Large-scale effects on bird assemblages in desert grasslands. Western North American Naturalist 70:19-25.

Burgi, M., A. Marino, V. Rodriguez, M. G. Pazos, and R. Baldi. 2011. Response of guanacos Lama guanicoe to changes in land management in Península Valdés, Argentine Patagonia: conservation implications. Oryx 46:99-105.

Burgi M, A. Marino, M. V. Rodriguez, G. Pazos, and R. Baldi. 2011. Response of guanacos Lama guanicoe to changes in land management in Península Valdés, Argentine Patagonia: conservation implications. Oryx 46:99-105.

Cartes J. L, E. Cuellar, H. Del Castillo, N. Neris, S. Saldivar, J. Thompson, AND M. Velilla. 2017. Cetartiodactyla y Perissodactyla: animales con pezuñas. Pp. 103-121 in Libro Rojo de los Mamíferos del Paraguay: especies amenazadas de extinción (V. Rojas Bonzi, J. Thompson, P. Smith, S. Saldivar Bellassai, N. De La Sancha, y J. Torres, eds.). Asociación Paraguaya de Mastozoología y Secretaría del Ambiente. Asunción, Paraguay.

Cassini, M., M. Borgnia, Y. Arzamendia, V. Benitez, and B. Vila. 2009. Sociality, Foraging and Habitat Use by Vicuñas. Pp. 35-48 in 
Vicuña: The Theory and Practice of Community Based Wildlife Management (Gordon, I. ed.). Springer Verlag. Berlin, Germany.

Chambers, F. M., D. Mauquoy, and P. A. Todd. 1999. Recent rise to dominance of Molinia caerulea in environmentally sensitive areas: new perspectives from palaeoecological data. Journal of Applied Ecology 36:719-733.

Cipriottı, P. A., And M. R. Aguiar. 2012. Direct and indirect effects of grazing constrain shrub encroachment in semi-arid Patagonian steppes. Applied Vegetation Science 15:35-47.

Chesson, J. 1978. Measuring preference in selective predation. Ecology 59:211-215.

Cook-Mena V., C. Chávez-Villavicencio, P. Martínez Palma and E. Tabilo-Valdivieso. 2019. Variation of the abundance of Lama guanicoe in Bosque Fray Jorge National Park (CoquimboChile) and its relationship with plant cover. Revista Peruana de Biología 26:481-490.

CoPPEDGE, B. 2004. Predicting juniper encroachment and CRP effects on avian community dynamics in southern mixedgrass prairie, USA. Biological Conservation 115:431-441.

Coppedge, B. R., D. M. Engle, R. E. Masters, and M. S. Gregory. 2001. Avian response to landscape change in fragmented southern Great Plains grasslands. Ecological Applications 11:47-59.

Cuéllar, E., and A. Fuentes. 2000. Censo aéreo de guanacos Lama guanicoe en el Chaco cruceño. Revista Boliviana de Ecología y Conservación Ambiental 8:83-90.

Cuéllar, E., AND A. Núñez. 2009. Lama guanicoe (Müller, 1776): Artiodactyla-Camelidae. Pp. 454-456 in Libro Rojo de la fauna silvestre de vertebrados de Bolivia Bolivia (Aguirre, L. F., R. Aguayo, J. Balderrama, C. Cortéz, and T. Tarifa, eds.). Ministerio de Medio Ambiente y Agua de Bolivia. La Paz, Bolivia.

Cuéllar, E., And A. J. Noss. 2014. Diversidad de mamíferos y participación local en la conservación en el Gran Chaco Boliviano. Therya 5:39-60.

Cuéllar-Soto, E., J. Segundo, and J. Banegas. 2017a. The guanaco in the Bolivian Gran Chaco: a review. Ecología en Bolivia 52:38-57.

Cuéllar-Soto, E., P. J. Johnson, and D. W. Macdonald. 2017 b. The diets of cattle and guanaco in the relict Chacoan savannahs of Bolivia. Ecología en Bolivia 52:77-87.

Cunazza, C., S. Puig, And L. Villalba. 1995. Situación actual del guanaco y su ambiente. Pp. 27-50 in Técnicas para el manejo del guanaco (Puig, S. ed.). IUCN. Gland, Switzerland.

Cunningham, M. A., And D. H. Johnson. 2006. Proximate and landscape factors influence grassland bird distributions. Ecological Applications 16:1062-1075.

Cushman, S. A. 2006. Effects of habitat loss and fragmentation on amphibians: A review and prospectus. Biological Conservation 128:231-240.

Devine, A. P., R. A. Macdonald, T. Quaife, and I. M. D. Maclean. 2017. Determinants of woody encroachment and cover in African savannas. Oecologia 183:939-951.

Donaldson, C. H. 1966. Control of blackthorn in the Molopo area with special reference to fire. Proceedings of the Grassland Society of South Africa 1:57-62.

EldRIDGe, D. J., M. A. Bowker, F. T. MAestre, E. Roger, J. F. Reynolds, AND W. G. Whitford. 2011. Impacts of shrub encroachment on ecosystem structure and functioning: towards a global synthesis. Ecology Letters 14:709-722.
Emmons, L. H. 1993. Mammals. Conservation International. Pp.101-103 in The Lowland Dry Forests of Santa Cruz, Bolivia, A Global Conservation Priority, Rapid Assessment Program, Working Papers 4. (Parker, T. A., A. H. Gentry, R. B Foster, L. H. Emmons, and J. V. Remsen Jr, eds.). Conservation International. Washington, U.S.A

Emmons, L. H. 2009. Long-Term Variation in Small Mammal Abundance in Forest and Savanna of Bolivian Cerrado. Biotropica 41:493-502.

Fahrig, L. 2002. Effect of habitat fragmentation on the extinction threshold: A synthesis. Ecological Applications 12:346-353.

Flores, C. E., A. M. Cingolani, A. Von müller, and F. R. Barri. 2012. Habitat selection by reintroduced guanacos (Lama guanicoe) in a heterogeneous mountain rangeland of central Argentina. The Rangeland Journal 34:439-445.

FrankLIN, W. L. 1982. Biology, ecology, and relationship to man of the South American camelids. Pp. 457-489 in Mammalian biology in South America (Mares, M. A. and H. H. Genoways, eds.). Pymatuning Laboratory of Ecology and University of Pittsburgh Press. Pittsburgh, U.S.A.

Franklin, W. L. 1983. Contrasting socioecologies of South America's wild camelids: the vicuña and the guanaco. Pp. 1-753 in Advances in the study of mammalian behavior (Eisenberg, J. F. and D. G. Kleiman, eds.). The American Society of Mammalogists. Shippensburg State College. Pennsylvania, U.S.A.

FrankLin, W. L., AND M. A. Fritz. 1991. Sustained harvesting of the Patagonia guanaco is it possible or too late? Pp. 317-336 in Neotropical Wildlife Use and Conservation. (Robinson, J. G., and K. H. Redford, eds.). University of Chicago Press. Chicago, U.S.A.

Garshelis, D. L. 2000. Delusions in Habitat Evaluation: Measuring Use, Selection, and Importance. Pp. 111-164 in Research Techniques in Animal Ecology: Controversies and Consequences. (Boitani, L., and T. K. Fuller, eds.). Columbia University Press, New York, U.S.A.

García Criado, M, I. H. Myers-Smith, A. D. Bjorkman, C. E. R. Lehmann, and

Gonzalez, B. A., R. E. Palma, B. Zapata, and J. C. Marin. 2006. Taxonomic and biogeographical status of guanaco Lama guanicoe (Artiodactyla, Camelidae). Mammal Review 36:157-178.

Graz, F. P. 2008. The woody weed encroachment puzzle: gathering pieces. Ecohydrology 1:340-348.

Hooge P. N., ANd B. Eichenlaub. 1997. Animal movement extension to ArcView. ver. 1.1. Alaska Science Center, Biological Science Office, U.S. Geological Survey, Anchorage, U.S.A.

Janssen, M. A., J. M. Anderies, And B. H. Walker. 2004. Robust strategies for managing rangelands with multiple stable attractors. Journal of Environmental Economics and Management 47:140-162.

Kavwele, C., J. Kımanzi, and M. Kinyanjul. 2017. Impacts of Bush Encroachment on Wildlife Species Diversity, Composition, and Habitat Preference in OI Pejeta Conservancy, Laikipia, Kenya. International Journal of Ecology 2017:1-6.

Kelly, M. J., A. J. Noss, M. S. Di bitetti, L. Maffel, R. L. Arispe, A. Paviolo, C. D. De Angelo, and Y. E. Di Blanco. 2008. Estimating Puma Densities from Camera Trapping across Three Study Sites: Bolivia, Argentina, and Belize. Journal of Mammalogy 89:408-418. 
Kenoyer, L. A. 1929. Plant Physiognomy. Ecology 10:409-414. Kgope, B. S., W. J. Bond, AND G. F. Midgley. 2010. Growth responses of African savanna trees implicate atmospheric $\mathrm{CO}_{2}$ as a driver of past and current changes in savanna tree cover. Austral Ecology 35:451-463.

Kimaro, H., A. Ayoub, L. Munishi, And A. C. Treydte. 2019. Woody Encroachment Extent and Its Associated Impacts on Plant and Herbivore Species Occurrence in Maswa Game Reserve, Tanzania. Environment and Natural Resources Research 9:63-76.

Knopf, F. 1994. Avian assemblages on altered grasslands. Studies in Avian Biology 15:247-257.

Krogh, S. N., M. S. Zeisset, E. Jackson, ANd W. G. Whitford. 2002. Presence/absence of a keystone species as an indicator of rangeland health. Journal of Arid Environments 50: 513-519.

Kulmatiskı A., And K. H. Beard. 2013. Root niche partitioning among grasses, saplings, and trees measured using a tracer technique. Oecologia 171:25-37.

Kunkel, K. E., And D. H. Pletscher. 2000. Habitat factors affecting vulnerability of moose to predation by wolves in southeastern British Columbia. Canadian Journal of Zoology 78:150-157.

Manly, B. F. J., P. Miller, And L. M. Cook. 1972. Analysis of a selective predation experiment. American Naturalist 106:719-736.

MaY, J. H., R. ZeCH, AND H. Veit. 2008. Late Quaternary paleosolsediment-sequences and landscape evolution along the Andean piedmont, Bolivian Chaco. Geomorphology 98:34-54.

Meik, J. M., R. M. Jeo, J. R. Mendelson, And K. E. Jenks. 2002. Effects of bush encroachment on an assemblage of diurnal lizard species in central Namibia. Biological Conservation 106:29-36.

Mendelson, J., And W. Jennings. 1992. Shifts in the relative abundance of snakes in a desert grassland. Journal of Herpetology 26:38-45.

Midgley, J., And W. Bond. 2001. A Synthesis of the Demography of African Acacias. Journal of Tropical Ecology 17:871-886.

Miller, S., J. Rottman, and R. Taber. 1973. Dwindling and endangered ungulates ofChile: Vicugna, Lama, Hippocamelus, and Pudu. Pp. 55-68 in North American Wildlife Natural Resources Conference. U.S.A.

Miserendino R. S., E. Cuéllar, and A. Noss. 1998. Diversidad de los mamíferos en el Izozog y el Área Natural de Manejo Integrado Kaa-lya del Gran Chaco, Santa Cruz, Bolivia. Ecología en Bolivia 31:17-31.

Moнr, C. O. 1947. Table of equivalent populations of North American small mammals. American Midland Naturalist 37:223-249.

Moncrieff, G. R., W. J. Bond, E. C. February, and S. ChamailleJammes. 2009. The megafaunal 'browse trap' and savanna vegetation structure. South African Journal of Botany 75:412-412.

Morello, J., AND J. Adamolı. 1974. Las grandes unidades de vegetación y ambiente del Chaco Argentino, Segunda Parte. Vegetación y Ambiente de la Provincia Chaco, Serie Fitogeografía 13:1-130.

Muñoz, A. E., And J. A. Simonettı. 2013. Diet of guanaco in sheep-free rangeland in Tierra del Fuego, Chile. Ciencia e Investigación Agraria 40:185-191.
Navarro, G. 2002. Ecología estructural y dinámica de áreas quemadas en el PN-ANMI Kaalya del Gran Chaco. Pp. 5-74 in Ecología del fuego en el Parque Nacional y Área Natural de Manejo Integrado Kaa-lya del Gran Chaco (Guerrero, J., ed.). Kaa-lya Project (CABI, WCS). Santa Cruz, Bolivia.

Navarro, G., And A. Fuentes. 1999. Geobotánica y sistemas ecológicos de paisaje en el Gran Chaco de Bolivia. Revista Boliviana de Ecología 5:25-50.

Okello, B. D. 2007. Effects of herbivores on the fire and harvesting population dynamics of Acacia drepanolobium Sjoestedt in Laikipia, Kenya. PhD. Dissertation, University of KwaZulu-Natal. Pietermaritzburg, South Africa.

Owen-Smith, N. 2008. Changing vulnerability to predation related to season and sex in an African ungulate assemblage. Oikos 117:602-610.

Pardiñas, U. F. J., And P. Teta. 2013. Holocene stability and recent dramatic changes in micromammalian communities of northwestern Patagonia. Quaternary International 305:127-140.

Pardiñas, U. F. J., D. E. Udrizar Sauthier, and P. Teta. 2012. Micromammal diversity loss in central-eastern Patagonia over the last 400 years. Journal of Arid Environments 85:71-75.

Parreño, V., V. Costantini, S. Cheetham, J. Blanco Viera, L. J. Saif, F. Fernández, L. Leoni, ANd A. Schudel. 2001. First Isolation of Rotavirus Associated with Neonatal Diarrhea in Guanacos (Lama guanicoe) in the Argentinean Patagonia Region. Journal of Veterinary Medicine 48:713-720.

Peel, M. C., B. L. Finlayson, and T. A. Mcmahon. 2007. Updated world map of the Koppen-Geiger climate classification. Hydrology and Earth System Sciences 11:1633-1644.

Pike, D., J. WebB, ANd R. Shine. 2011. Removing forest canopy cover restores a reptile assemblage. Ecological Applications 21:274-280.

Pinto, C., And E. Cuéllar-Soto. 2017. Multi-temporal analysis of a vegetation mosaic form by a serial stage of the Chacoan forest on well-drained soils, Kaa-lya del Gran Chaco National Park. Ecología en Bolivia 52:7-20.

Politis, G., L. Prates, M. Merino, And M. Tognelli. 2011. Distribution parameters of guanaco (Lama guanicoe), pampas deer (Ozotoceros bezoarticus) and marsh deer (Blastocerus dichotomus) in Central Argentina: Archaeological and paleoenvironmental implications. Journal of Archaeological Science 38:1405-1416.

Prins, H. T., And M. Rietkerk. 2003. Effects of fire and herbivory on the stability of savanna ecosystems. Ecology 84:337-350.

Puig, S., F. Videla, M. I. Cona, And S.A. Monge. 2001. Use of food availability by guanacos (Lama guanicoe) and livestock in Northern Patagonia (Mendoza, Argentina). Journal of Arid Environments 47:291-308.

Puig, S., F. Videla, M. I. Cona, And V. G. Roig. 2008. Habitat use-by guanacos (Lama guanicoe, Camelidae) in northern Patagonia (Mendoza, Argentina). Studies on Neotropical Fauna and Environment 43:1-9.

Puig, S., M. Rosı, F. Videla, And E. Méndez. 2011. Summer and winter diet of the guanaco and food availability for a High Andean migratory population (Mendoza, Argentina). Mammalian Biology 76:727-734.

Puig, S., F. Videla, M. I. Rosı, And V. P. Seitz. 2019. Influence of environmental variables and human activities on the 
seasonal habitat use by guanacos in Southern Andean Precordillera (Argentina). Studies on Neotropical Fauna and Environment 54:191-205.

Raedeke, K. J., And J. A. Simonettı. 1988. Food Habits of Lama guanicoe in the Atacama Desert of Northern Chile. Journal of Mammalogy 69:198-201.

Ratajczak, Z., J. Nippert, and S. Collins. 2012. Woody encroachment decreases diversity across North American grasslands and savannas. Ecology 93:697-703.

Redford, K. H., A. Taber, And J. A. Simonetti. 1990. There is more to biodiversity than the tropical rainforests. Conservation Biology 4:328-330.

Riginos, C., and J. B. Grace. 2008. Savanna tree density, herbivores, and the herbaceous community: Bottom-up vs. top-down effects. Ecology 89:2228-2238.

Risenhoover, K. L., And J. A. Bailey. 1985. Foraging ecology of mountain sheep - implications for habitat management. Journal of Wildlife Management 49:797-804.

Sala, O. E., And F. T. Maestre. 2014. Grass-woodland transitions: Determinants and consequences for ecosystem functioning and provisioning of services. Journal of Ecology 102: 1357-1362.

Sankaran M., N. P. Hanan, R. J. Scholes, J. Ratnam, D. J. Augustine, B. S. Cade, J. Gignoux, S. I. Higgins, X. Le Roux, F. Ludwig, J. Ardo, F. Banyikwa, A. Bronn, G. Bucini, K. K. Caylor, M. B. Coughenour, A. Diouf, W. Ekaya, C. J. Feral, E. C. February, P. G. Frost, P. Hiernaux, H. Hrabar, K. L. Metzger, H. H. Prins, S. Ringrose, W. Sea, J. Tews, J. Worden, and N. Zambatis. 2005. Determinants of woody cover in African savannas. Nature 438:846-849.

Scheffer, M., S. Carpenter, J. A. Foley, C. Folke, and B. Walker. 2001. Catastrophic shifts in ecosystems. Nature 413:591-596.

SERFOR. 2018. Libro Rojo de la Fauna Silvestre Amenazada del Perú. Editorial. Lima, Perú.

Sirami, C., and A. Monadjem. 2012. Changes in bird communities in Swaziland savannas between 1998 and 2008 owing to shrub encroachment. Diversity and Distributions 18: 390-400.

Sirami, C., C. Seymour, G. Midgley, and P. Barnard. 2009. The impact of shrub encroachment on savanna bird diversity from local to regional scale. Diversity and Distributions 15:948-957.

Skowno, A., AND W. Bond. 2003. Bird community composition in an actively managed savanna reserve, importance of vegetation structure and vegetation composition. Biodiversity and Conservation 12:2279-2294.

Smit I. P. J, And H. H. T. Prins. 2015. Predicting the Effects of Woody Encroachment on Mammal Communities, Grazing Biomass and Fire Frequency in African Savannas. Plos One 10:e0137857.

Sosa, R. A., and J. H. Sarasola. 2005. Habitat use and social structure of an isolated population of guanacos (Lama guanicoe) in the Monte Desert, Argentina. European Journal of Wildlife Research 51:207-209.

South, A. B., R. E. Kenward, And S. S. Walls. 2005. Ranges7 v1: For the analysis of tracking and location data. Online manual. Anatrack Ltd. Wareham, U.K.

Steenkamp, H. E., And S. L. Chown. 1996. Influence of dense stands of an exotic tree, Prosopis glandulosa Benson, on a savannah dung beetle (Coleoptera: Scarabaeinae) assemblage in southern Africa. Biological Conservation 78:305-311.

Stevens, N. 2020. Woody plant encroachment intensifies under climate change across tundra and savanna biomes. Global Ecology and Biogeography 29:925-943.

Stevens, N., C. E. R. Lehmann, B. P. Murphy, and G. Durigan. 2017. Savanna woody encroachment is widespread across three continents. Global Change Biology 23:235-244.

Stuewe, M., And H. Hendrichs. 1984. Organization of roe deer Capreolus capreolus in an open field habitat. Zeitschrift fuer Saeugetierkunde 49:359-367.

Skowno, A., AND W. Bond. 2003. Bird community composition in an actively managed savanna reserve, importance of vegetation structure and vegetation composition. Biodiversity and Conservation 12:2279-2294.

Taber, A., G. Navarro, and M. A. Arribas. 1997. A new park in the Bolivian Gran Chaco - An advance in tropical dry forest conservation and community-based management. Oryx 31:189-198.

Tonnl, E. P. And G. Politis. 1980. La distribución del guanaco (Mammalia, Camelidae) en la provincia de Buenos Aires durante el Pleistoceno Tardío y Holoceno. Los factores climáticos como causas de su retracción. Ameghiniana 17:53-66.

Travaini, A., J. Bustamante, A. Rodríguez, S. Zapata, D. Procopio, J. Pedrana, and R. Martínez Peck. 2007. An integrated framework to map animal distributions in large and remote regions. Diversity and Distributions 13:289-298.

UNDERWOOD, R. 1982. Vigilance behaviour in grazing African antelopes. Behaviour 79: 81-107.

Van Auken, O. W. 2000. Shrub invasions of North American semiarid grasslands. Annual Review of Ecology and Systematics 31:197-215.

Van Langevelde, F., C. A. D. M. Van de Vijver, L. Kumar, J. Van de Koppel, N. De Ridder, J. Van Andel, A. K. Skidmore, J. W. Hearne, L. Stroosnijder, W. J. Bond, H.H.T. Prins and M. RietKerk. 2003. Effects of fire and herbivory on the stability and herbivory on the stability of savanna ecosystems. Ecology 84:337-350.

Weber, J. 2000. Uso de hábitat y densidad poblacional del Guanaco (Lama guanicoe voglii) en las Pampas de Guaipa y Rancho Chico, Alto Isoso, Provincia Cordillera. Santa Cruz. Santa Cruz, Bolivia, Gabriel René Moreno University. Undergraduate thesis.

Villalba, M. L. 1992. The guanaco, Bolivia. IUCN/SSC South American Camelids Specialist Group. Gland, Switzerland.

Wigley, B. J., W. J. Bond, And M. T. Hoffman. 2010. Thicket expansion in a South African savanna under divergent land use: local vs. global drivers? Global Change Biology 16:964-976.

Associated editor: Rafael Reyna

Submitted: May 9, 2020; Reviewed: June 1, 2020;

Accepted:September 23, 2020; Published on line: September 29, 2020. 